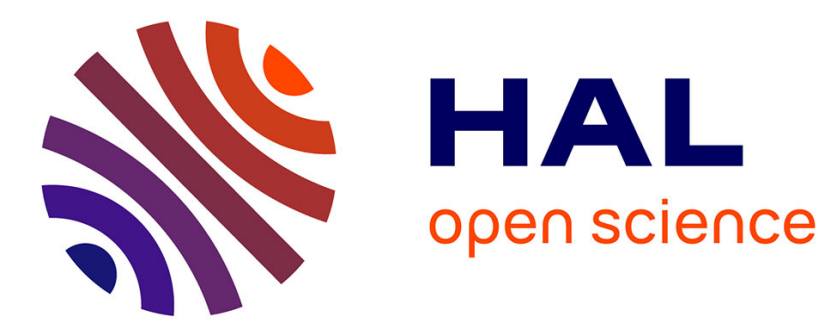

\title{
Travel and tick-borne diseases: Lyme disease and beyond
} Philippe Parola, Christopher D. Paddock

\section{To cite this version:}

Philippe Parola, Christopher D. Paddock. Travel and tick-borne diseases: Lyme disease and beyond. Travel Medicine and Infectious Disease, 2018, 26, pp.1-2. 10.1016/j.tmaid.2018.09.010 . hal01970230

\section{HAL Id: hal-01970230 \\ https://hal.science/hal-01970230}

Submitted on 10 Apr 2019

HAL is a multi-disciplinary open access archive for the deposit and dissemination of scientific research documents, whether they are published or not. The documents may come from teaching and research institutions in France or abroad, or from public or private research centers.
L'archive ouverte pluridisciplinaire HAL, est destinée au dépôt et à la diffusion de documents scientifiques de niveau recherche, publiés ou non, émanant des établissements d'enseignement et de recherche français ou étrangers, des laboratoires publics ou privés. 
On a global scale, ticks are second only to mosquitoes as the most important of vectors of infectious disease agents of humans [1]. Ticks transmit a greater diversity of viral, bacterial and protozoan infections than any other arthropod on earth, and in many temperate regions of the world, including Europe and the United States, tick-borne diseases (TBD) are the most widespread and medically important of all vectorborne infections. Lyme borreliosis, caused by Borrelia burgdorferi sensu lato species and transmitted by various Ixodes spp., afflicts tens and possibly hundreds of thousands of persons in the Northern Hemisphere each year and has brought the subject of TBD to general attention more than any other associated infection. Nonetheless, the scope and magnitude of other TBD have expanded worldwide: both in the United States and Europe, 14 newly recognized TBD have been identified in only the last 25 years [2].

All tick species favor particular environmental conditions and biotopes that determine their geographic distribution and consequently the areas of risk for TBD. This geographical aspect of TBD is an important issue in the context of travel medicine. The growth of international tourism to rural, tropical or remote areas, visits to friends and relatives in other countries, and travel related to military work or foreign aid development increasingly expose travelers to tick bites and TBD. Ticks from one regions of the world can serve as vectors of various pathogens that often are unknown to physicians from other parts of the world. Even Lyme disease can be misdiagnosed in patients who travel to areas of the Northern hemisphere where the disease is endemic and subsequently return to southern countries where the vectors are absent and the disease is not known or considered by regional health care providers [1]. In a similar manner, the numbers of travel-related cases of tick-borne encephalitis are probably underestimated since there is little awareness of this disease in countries where the pathogen is not endemic and often seroepidemiological studies are the first to the extent of exposure to TBD [3].

Tick-borne rickettsial diseases are among the best examples of emerging infections, described in travelers [4]. African tick bite fever
(ATBF) caused by Rickettsia africae and transmitted through the bite of Amblyomma ticks, occurs commonly among travelers returning from safaris or visits to game parks or reserves and represent the second most frequently identified cause of fever after malaria in travelers returning from sub-Saharan Africa $[1,4,5]$. Since these ticks are aggressive, attack people, and with an infection rate by $R$. africae up to $100 \%$ in some places, clusters of patients presenting with multiple inoculation eschars are frequent. Other tick-borne rickettsioses that have been reported in travelers include Mediterranean spotted fever (caused by Rickettsia conorii conorii), Rocky Mountain spotted fever (caused by Rickettsia rickettsii) as well as several recently identified infections caused by Rickettsia massiliae, Rickettsia sibirica mongolitimonae, and Rickettsia slovaca. Since some of these diseases may have a fatal outcome, a prompt treatment with doxycycline should be started as soon as the disease is suspected clinically New diagnostic methods have been developed for the diagnosis of TBD. In particular, PCR-based tests of eschar swabs or crust samples can facilitate rapid diagnosis of various eschar-associated rickettsioses [5]. If retained, ticks that bite patients can be identified and tested by molecular tools to assess the risk of infection.

Tick-borne relapsing fevers (TBRF), transmitted by soft ticks of the genus Ornithodoros and caused by various Borrelia spp., are even less known in the field of travel medicine, although they represent a major public health problem in some areas. TBRF are acute febrile illnesses followed by multiple recurrences of fever linked to spirochaetemia, headache, and possible neurological complications. These infections are cannot be distinguished clinically from other acute undifferentiated febrile illnesses like malaria [1] and therefore require confirmatory laboratory tests.

Minimizing the risk of tick bites remain the most important measure to reduce the risk of TBD. This can be accomplished by wearing long pants that are tucked into boots and by applying tick repellents and acaricides. Inspecting for and removing attached ticks with tweezers or forceps as soon as possible following exposures to tick-infested areas is 
another important consideration. Finally, because most bacterial infections transmitted by ticks are susceptible to doxycycline, malaria prophylaxis with doxycycline might also provide protection against many TBD.

\section{References}

[1] Eldin C, Parola P. Update on tick-borne bacterial diseases in travelers. Curr Infect Dis Rep 2018;20:17.

[2] Paddock CD, Lane RS, Staples JE, Labruna MB. Changing paradigms for tick-borne diseases in the Americas Institute of Medicine Global health impacts of vector borne diseases: workshop summaryWashington, DC: The National Academies Press; 2016. p. 221-58.

[3] Dzelalija B, Punda-Polic V, Medic A, Dobec M. Rickettsiae and rickettsial diseases in Croatia: implications for travel medicine. Trav Med Infect Dis 2016 Sep Oct;14(5):436-43. https://doi.org/10.1016/j.tmaid.2016.06.010.

[4] Delord M, Socolovschi C, Parola P. Rickettsioses and Q fever in travelers (2004-
2013). Trav Med Infect Dis 2014;12:443-58

[5] Cherry CC, Denison AM, Kato CY, Thornton K, Paddock CD. Diagnosis of spotted fever group rickettsioses in U.S. travelers returning from Africa, 2007-2016. Am Trop Med Hyg 2018;99:136-42

Philippe Parola* Aix Marseille Univ, IRD, AP-HM, SSA, VITROME, IHU-Méditerranée Infection, Marseille, France

Christopher D. Paddock Rickettsial Zoonoses Branch, Division of Vector-Borne Diseases, National Center for Emerging and Zoonotic Infectious Diseases, Centers for Disease

Control and Prevention, Atlanta, GA, USA E-mail address: philippe.parola@univ-amu.fr (P. Parola)

${ }^{*}$ Corresponding author. VITROME, Institut Hospitalo-Universitaire Méditerranée Infection, 19-21 boulevard Jean Moulin, 13005 Marseille, France. 